\title{
Determinants of COVID-19 self-protection behavior of Thai people: a cross-sectional survey
}

\author{
Benjawee Srithanissorn ${ }^{1}$, Kritsana Yonphet ${ }^{1}$, Daranee Chiewchantanakit ${ }^{2}$, \\ Witoo Dilokthornsakul1,2*, Piyameth Dilokthornsakul1,2 \\ 1 Center of Pharmaceutical Outcomes Research, Department of Pharmacy Practice, Faculty of Pharmaceutical Sciences, Naresuan University, Mueang,
Phitsanulok, Thailand \\ 2 Department of Pharmacy Practice, Faculty of Pharmaceutical Sciences, Naresuan University, Mueang, Phitsanulok, Thailand
}

\begin{abstract}
Background: Coronavirus disease 2019 (COVID-19) pandemic is a critical situation since 2020. Its outbreak occurs across the world. A national policy is to promote self-protection behavior including hand wash, wearing mask, and physical distancing. However, evidence on determinants of the behavior in Thai people is limited. This study aimed to identify determinants of COVID-19 self-protection behavior in Thai people.

Design and Method: A cross-sectional survey was undertaken in January 2021. An online questionnaire was developed under the Health Belief Model (HBM). Participants who often or always behave COVID-19 self-protection was considered as proper self-protection behavior. Data was collected through social medias.

Results: A total of 408 participants was included. Of those, 92 participants $(22.5 \%)$ were male with the average age of $32.3 \pm 11.5$ years. A total of 158 participants (38.7\%) has proper self-protection behavior. Based on $\mathrm{HBM}$, perceived threat [odds ratio $(\mathrm{OR})=1.40,95 \% \mathrm{CI} 1.01-1.92$ ], perceived barriers $(\mathrm{OR}=0.51,95 \% \mathrm{CI} ; 0.36-0.71)$, and perceived self-efficacy $(\mathrm{OR}=6.77,95 \% \mathrm{CI} ; 3.60-12.72)$ were significantly associated with self-protection behavior.

Conclusion: One-third of participants have proper COVID-19 self-protection behavior. Perceived selfefficacy is the strongest determinant of COVID-19 self-protection behavior followed by perceived threat and perceived barriers.
\end{abstract}

\section{Keywords:}

COVID-19, Determinants, Physical distancing, Handwashing, Wearing mask, Health Belief Model

\section{INTRODUCTION}

Coronavirus disease 2019 (COVID-19) is firstly discovered in China since December 2019 and the pandemic of COVID-19 has been rapidly occurred and recognized as the important global health problem in $2020^{1-2}$. Most infected people develops mild to moderate respiratory symptoms including fever, dry cough, headache, sore throat, and weakness ${ }^{3-4}$. However, serious acute respiratory distress syndrome and multiple organ failures could develop especially in elderly who have medical conditions such as cancer, chronic kidney disease, diabetes mellitus and cardiovascular disease ${ }^{5}$.

The coronavirus (SAR-CoV2), which causes COVID-19, transmits from person to person via droplets through talking, coughing, sneezing, and touching contaminated surface ${ }^{6}$. Therefore, isolation, strict quarantine, and physical distancing have been recommended to prevent COVID-19 pandemic ${ }^{7}$. Even vaccination is an important tool to stop the spread of COVID-19, the availability and distribution of COVID-19 vaccines are limited. Therefore, the World Health Organization (WHO), the Department of Disease Control of Thailand (DDC), and Thai Health Promotion Foundation promote self-protection campaign to protect Thai people from COVID-19. Three important COVID-19 self-protection behaviors are recommended including hand washing with soap or alcohol gel, wearing a mask, and physical distancing by spacing 1-2 meters between others, ${ }^{4,-10}$.

The success of the self-protection campaign is

*Corresponding author:

*Witoo Dilokthornsakul witool@nu.ac.th 
to change human behavior, therefore, some health behavior theories could be applied to explain and encourage health behavior changes. One of the appropriate theories is the Health Belief Model (HBM) $)^{11-14}$. It explains human behavior through five perceptions of individuals including perceived susceptibility, perceived severity, perceived benefits, perceived barriers, and perceived self-efficacy and one cue to actions. The theory could explain key determinants of COVID-19 self-protection behavior. Therefore, this study aimed to identify determinants of COVID-19 self-protection behavior in Thai people through the HBM framework. The results could provide important information to support policy makers for the improvement of COVID-19 self-protection campaign among Thai people.

\section{MATERIALS AND METHODS}

\subsection{Study design}

A cross-sectional survey was undertaken to identify significant determinants of COVID-19 selfprotection behavior among Thai people. The study was approved by the research committee of Naresuan University Institutional Review Board (NU-IRB) (No. P10167/ 63 ). The consent form was provided by subjects through Google form ${ }^{\circledR}$ at the beginning of online questionnaires.

\subsection{Subject selection}

The study's population was Thai people who lived in Thailand during 2020-2021. Thai people who met the following inclusion criteria were eligible. The inclusion criteria were: 1) aged 20 years and above, 2) be able to read Thai language, 3) be able to access and use the internet network to complete the online questionnaires, and 4) voluntary participation.

\subsection{Questionnaire development}

An online survey questionnaire using a Google form ${ }^{\circledR}$ was developed to evaluate COVID-19 self-protection behavior during the period of the first relaxed coronavirus lockdown in Thailand from May to December 2020 which was the time before the second wave of COVID-19 outbreak in Thailand. The questionnaire consisted of 39 items and were classified into three parts. The first part was the subject characteristics (8 items). The second part aimed to assess COVID-19 self-protection behavior which were recommended by the WHO, and Thai DDC related to COVID-19 selfprotection guidance including 4 items for handwashing with soap or alcohol gel (before eating food, after using toilet, after coughing/sneezing, and after touching objects in a public place), 1 item for wearing mask in public place, and 1 item for physical distancing in public place.
The response options of these two parts were 5-levels Likert scale as "1-Never", "2-Rarely", "3-Sometime", "4-Often" and "5-Always". The third part of the questionnaire composed of 25 items which were constructed under the HBM framework to identify key determinants of COVID-19 self-protection behavior. The perceptions of disease susceptibility, disease severity, benefits to action, barrier to action, self-efficacy, and cue to actions were evaluated on 5-levels Likert scale from 1-strongly disagree to 5-strongly agree. Content validity of the questionnaire was assessed by Item-Objective Congruence (IOC) index. Reliability of the questionnaire was also assessed by Cronbach's alpha. The Cronbach's alpha of this questionnaire was 0.752 .

\subsection{Data collection}

The questionnaire was distributed to subjects through social media platforms including Facebook®, Instagram ${ }^{\circledR}$ and Twitter ${ }^{\circledR}$ in January 2021 . The platforms were frequently monitored to response to subjects' questions (if any) and the Google form ${ }^{\circledR}$ was also monitored daily to determine the number of subjects. The data collection was stopped when the number of participants reached the estimated sample size (400 subjects).

\subsection{Outcomes and analysis}

Prevalence of COVID-19 self-protection behavior including hand washing with soap or alcohol gel, wearing mask and physical distancing were estimated. Subjects who rated each particular COVID-19 selfprotection behavior as 4-Often or 5-Always were considered as proper for each behavior. Specifically, subjects were classified as proper handwashing behavior when they rated 4-Often or 5-Always for all 4 items of handwashing behavior. Subjects who rated all COVID-19 self-protection behavior as 4-Often or 5-Always were considered as proper COVID-19 self-protection behavior.

Descriptive statistics were used to describe subjects' characteristics. A multiple logistic regression was performed to identify significant determinants of proper COVID-19 self-protection behavior and presented as odds ratio (OR) with its corresponding $95 \%$ confidence interval. Multiple linear regression was also performed to associate modifying factors and each specific perception. All statistical analyses were performed using STATA package version 15.0 (StataCorp LP, college station, TX, USA)

\section{RESULTS}

\subsection{Subject's characteristics}

A total of 408 subjects completed this online 
Table 1. Demographic data.

\begin{tabular}{|c|c|}
\hline Characteristics $(n=408)$ & n $(\%)$ \\
\hline \multicolumn{2}{|l|}{ 1. Genders } \\
\hline Male & $92(22.55)$ \\
\hline Female & $305(74.75)$ \\
\hline Lesbian, gay, bisexual, and transgender & $6(1.47)$ \\
\hline Not identified & $3(0.74)$ \\
\hline \multicolumn{2}{|l|}{ 2. Age (years), mean $=32.29 \pm 11.54$} \\
\hline $20-29$ & $232(56.86)$ \\
\hline $30-39$ & $71(17.40)$ \\
\hline $40-49$ & $58(14.22)$ \\
\hline $50-59$ & $36(8.82)$ \\
\hline $60-69$ & $10(2.45)$ \\
\hline 70+years & $1 \quad(0.25)$ \\
\hline \multicolumn{2}{|l|}{ 3. Educations } \\
\hline Elementary school & $3(0.74)$ \\
\hline Junior high school & $13(3.19)$ \\
\hline Senior high school/vocational certificate & $48(11.76)$ \\
\hline Diploma/vocational certificate & 15 (3.68) \\
\hline Bachelor's degree or higher & $313(76.72)$ \\
\hline \multicolumn{2}{|l|}{ 4. Occupations } \\
\hline Government/state employee & $128(31.37)$ \\
\hline Students & $106(25.98)$ \\
\hline Healthcare personnel & $27(6.62)$ \\
\hline Merchant/self-employed & $25 \quad(6.13)$ \\
\hline Teachers & $23 \quad(5.64)$ \\
\hline General contractor & $23 \quad(5.64)$ \\
\hline Public driver & $3(0.74)$ \\
\hline Agriculturist & $3(0.74)$ \\
\hline Security guard & $1 \quad(0.25)$ \\
\hline Others & $38 \quad(9.31)$ \\
\hline unemployed & $27 \quad(6.62)$ \\
\hline \multicolumn{2}{|l|}{ 5. Average income (bath/month) } \\
\hline$<500$ & $12(2.94)$ \\
\hline $500-3,000$ & $19(4.66)$ \\
\hline $3,001-10,000$ & $98(24.02)$ \\
\hline $10,001-30,000$ & $179(43.87)$ \\
\hline $30,001-50,000$ & $66(16.18)$ \\
\hline $50,001-100,000$ & $17(4.17)$ \\
\hline$>100,000$ & $10 \quad(2.45)$ \\
\hline \multicolumn{2}{|l|}{ 6. Chronic diseases } \\
\hline Were not diagnosed & $317(77.70)$ \\
\hline Diagnosed & $89(21.81)$ \\
\hline Hypertension (HTN) & $13(3.19)$ \\
\hline Diabetes mellitus (DM) & $6(1.47)$ \\
\hline Cardiovascular disease (CVD) & $1(0.25)$ \\
\hline Lung disease & - \\
\hline Others & $69(16.91)$ \\
\hline \multicolumn{2}{|l|}{ 7. Family members (not include the respondent) } \\
\hline Living with other family members & $306(75.00)$ \\
\hline Age $>50$ years & $208(50.98)$ \\
\hline Chronic disease; HTN, DM, CVD, and Lung disease & $132(32.35)$ \\
\hline Pregnancy/puerperium period & $7(1.72)$ \\
\hline Children $<5$ years & $43(10.54)$ \\
\hline
\end{tabular}

survey. Of those, 305 subjects were female $(74.75 \%)$ with the average age of $32.29 \pm 11.54$ years. The majority earned the bachelor's degree (76.72\%).One hundred and twenty-eight subjects (31.37\%) were government or state employee, and 179 subjects (43.87\%) had an average income of 10,001-30,000 Thai baht/month. Most subjects $(77.70 \%)$ were not diagnosed as chronic diseases (77.70\%), and lived with other family members $(75.00 \%)$
(Table 1).

\subsection{Prevalence of COVID-19 self-protection behavior}

The average scores of handwashing with soap or alcohol gel ranged from $3.66 \pm 1.18$ (for handwashing after coughing/sneezing) to $4.41 \pm 0.87$ (for handwashing after touching objects in a public place). The average 
score of wearing a mask in a public place was $4.88 \pm 0.40$, while the average score of physical distancing was $3.87 \pm$ 0.96 (Table 2).

According to our operational definition, we found that 200 subjects $(49.02 \%)$ had proper handwashing, 400 subjects (98.04\%) had proper mask wearing, and 276 subjects $(67.65 \%)$ had proper physical distancing. We also found that 158 subjects (38.73\%) had proper COVID-19 self-protection behavior (Table 2). Details of each item of COVID-19 self-protection behavior is presented in appendix (Table A1).

\subsection{Determinants of proper COVID-19 self-protection behavior}

According to HBM, perceived self-efficacy was the strongest determinant of proper COVID-19 selfprotection behavior $(\mathrm{OR}=6.77,95 \% \mathrm{CI} ; 3.60-12.72)$. Other significant determinants were perceived threat $(\mathrm{OR}=$ $1.10,95 \% \mathrm{CI} ; 0.10-1.92)$, and perceived barriers $(\mathrm{OR}=0.51$, 95\%CI; 0.36-0.71). The detail of determinants of proper COVID-19 self-protection behavior and each specific behavior is presented in Table 3 and frequency distribution of answers to questions based on the HBM is presented in Table A2.

\subsection{Association between modifying factors and indi- vidual perceptions}

The association between modifying factors and individuals' perceptions were assessed using multiple linear regression. We found that age was significantly associated with perceived severity, perceived barrier and perceived self-efficacy, while gender was associated with perceived benefits and perceived self-efficacy. In addition, income was associated with perceived benefit, and living with patients with chronic diseases was reversely associated with perceived barriers. All significant modifying factors of each individual perceptions are reported in Table 4.

\section{DISCUSSION}

This study investigates prevalence of COVID19 self-protection behavior among Thai people and identifies significant determinants of COVID-19 selfprotection behavior using HBM framework. Thirtyeight percent of subjects have proper COVID-19 selfprotection behavior. Perceived self-efficacy, perceived threat, and perceived barriers are significant determinants of COVID-19 self-protection behavior.

Only one-third of subjects have proper COVID-19 self-protection behavior, which is relatively low. It might be due to our strong operational definition for proper behavior. Only subjects who rated all COVID19 self-protective behavior as 4-Often or 5-Always are classified as proper COVID-19 self-protection behavior. When we classify subjects with proper COVID-19 selfprotection behavior as 2 out of 3 sub-behaviors should be rated as 4-Often or 5-Always, prevalence of proper COVID-19 self-protection behavior could be higher. However, we intent to use the current operational definition to reflect the best practice as recommended by WHO and Thai DDC. We believe that it will help policy makers to better evaluate the current situation of COVID19 self-protection.

According to the observed prevalence of each COVID-19 self-protection behavior, almost all subjects (98.04\%) have proper mask wearing in public area. More than half $(67.65 \%)$ have proper physical distancing but only half of subjects (49.02\%) have proper handwashing behavior. The low prevalence of proper handwashing might be because we require subjects to behave proper handwashing for all four situations as handwashing before eating food, handwashing after using toilet, handwashing after coughing/sneezing, and handwashing after touching objects in public place. The average scores of handwashing ranged from $3.66 \pm 1.18$ for handwashing after coughing or sneezing to $4.41 \pm$ 0.87 for handwashing after touching objects in public place. The low prevalence of proper handwashing behavior could also affect the overall prevalence of proper COVID-19 self-protection behavior. Because the coronavirus could spread via droplets through coughing, sneezing, and touching contaminated surface, handwashing could be one of the cheap and effective intervention to protect people from COVID-19 infection ${ }^{15}$. Therefore, proper handwashing behavior campaign should be intensely promoted to encourage COVID-19 self-protection behavior among Thai people.

Health Belief Model is widely used to identify significant determinants of COVID-19 self-protection behavior in several countries ${ }^{16-18}$. A study from Iran indicated that perceived self-efficacy and perceived barriers were significant determinants of COVID-19 self-protection behavior ${ }^{16}$, while a study from Ethiopia revealed that perceived self-efficacy, perceived benefits, perceived barriers, and perceived susceptibility were significant determinants of COVID-19 of adherence to COVID-19 self-protection behavior ${ }^{17}$. In addition, perceived severity was the most significant determinant in Morocco and perceived susceptibility was the strongest determinant in India ${ }^{18}$. Our findings indicated that perceived self-efficacy, perceived threat, and perceived barriers were the significant determinants of COVID-19 self-protection behavior. The variations of important determinants of COVID-19 self-protection behavior across countries might be due to differences in culture, belief, COVID-19 situations, and health communications of COVID-19 in each country.

According to HBM, perceived self-efficacy refers to personal perception about their competence to 
successfully engage to health-protective behavior. The perceived self-efficacy is recognized as one of key determinants of health behavior change ${ }^{11}$. Therefore, public health communication strategies which encourage self-efficacy of individuals should be implemented to improve COVID-19 self-protection behavior among Thai people.

Perceived threat is the combination of perceived susceptibility and perceived severity ${ }^{11}$. They depend on knowledge of health conditions. Individuals, who feel more susceptible to being illness or perceived the conditions as serious problems, are more likely to comply with health preventive behavior ${ }^{14}$. Therefore, public health communication strategies which provide comprehensive knowledge of susceptibility and severity of COVID-19 could help individuals to improve COVID19 self-protection behavior.

Perceived barriers is defined as the perception of inconvenience, dangerous or discomfort to action which leads to decline disease prevention ${ }^{11}$. In our study,

Table 2. Prevalence of COVID-19 self-protective behaviors.

\begin{tabular}{lcc}
\hline Self-protective behaviors & Action*n (\%) & Score 1-5 $\bar{x} \pm$ SD \\
\hline 1. Hand washing with soap/alcohol hand gel & $200(49.02)^{\mathrm{a}}$ & - \\
1.1 Before eating food & $312(76.47)$ & $4.09 \pm 0.98$ \\
1.2 After using toilet & $331(81.13)$ & $4.30 \pm 1.00$ \\
1.3 After coughing/sneezing & $250(61.27)$ & $3.66 \pm 1.18$ \\
1.4 After touching objects in a public place & $343(84.07)$ & $4.41 \pm 0.87$ \\
\hline 2. Wearing mask in public place & $400(98.04)$ & $4.88 \pm 0.40$ \\
\hline 3. Physical distancing in public place & $276(67.65)$ & $3.87 \pm 0.96$ \\
\hline 4. Proper COVID-19 self-protection behaviors & $158(38.73)^{\mathrm{b}}$ & - \\
\hline
\end{tabular}

*Often or always

a: Often or always in all of 1.1-1.4

b: Often or always follow all of the recommended self-protection behaviors including hand washing with soap/alcohol hand gel, wearing a mask in a public place and physical distancing (spacing 1-2 meters) in a public place.

Table 3. Determinant of proper COVID-19 self-protection behaviors.

\begin{tabular}{lllcc}
\hline $\begin{array}{l}\text { The construct of HBM with } \\
\text { proper self-protective } \\
\text { behaviors }\end{array}$ & Hand washing & Wearing mask & Physical distancing & $\begin{array}{l}\text { Proper COVID-19 } \\
\text { self-protection behaviors }\end{array}$ \\
\cline { 2 - 5 } & $1.29[0.97-1.73]^{\wedge}$ & $1.28[0.47-3.53]$ & $1.15[0.83-1.61]$ & $1.40[1.01-1.92]^{\wedge}$ \\
\hline Perceived threat & $0.79[0.51-1.21]$ & $1.55[0.77-3.11]$ & $1.25[0.80-1.96]$ & $0.87[0.54-1.39]$ \\
\hline Perceived benefits & $0.68[0.51-0.91]^{\wedge}$ & $0.34[0.13-0.88]^{\wedge}$ & $0.70[0.50-0.98]^{\wedge}$ & $0.51[0.36-0.71]^{\wedge}$ \\
\hline Perceived barriers & $3.32[2.04-5.39]^{\wedge}$ & $1.62[0.61-4.29]$ & $5.91[3.23-10.83]^{\wedge}$ & $6.77[3.60-12.72]^{\wedge}$ \\
\hline Perceived self-efficacy & $1.44[1.02-2.04]^{\wedge}$ & $1.53[0.60-3.87]$ & $0.93[0.62-1.40]$ & $1.28[0.86-1.91]$ \\
\hline Cues to actions & & & &
\end{tabular}

Table 4. Association between modifying factors and individual perceptions.

\begin{tabular}{|c|c|c|c|c|}
\hline & \multirow[t]{2}{*}{ Beta coefficient } & \multicolumn{2}{|c|}{$95 \% \mathrm{CI}$} & \multirow[t]{2}{*}{$P$-value } \\
\hline & & Min & Max & \\
\hline \multicolumn{5}{|l|}{ Perceived susceptibility } \\
\hline No modifying factors & - & - & - & - \\
\hline \multicolumn{5}{|l|}{ Perceived severity } \\
\hline Age $40-49$ years old & 0.22 & 0.03 & 0.41 & 0.025 \\
\hline Age $50-59$ years old & 0.32 & 0.09 & 0.55 & 0.007 \\
\hline \multicolumn{5}{|l|}{ Perceived benefits } \\
\hline Female & 0.20 & 0.07 & 0.33 & 0.002 \\
\hline Income $15,001-50,000$ bath/month & 0.15 & 0.04 & 0.26 & 0.007 \\
\hline \multicolumn{5}{|l|}{ Perceived barriers } \\
\hline Age $30-39$ years old & -0.45 & -0.66 & -0.24 & 0.000 \\
\hline Age 40-49 years old & -0.53 & -0.76 & -0.30 & 0.000 \\
\hline Age $50-59$ years old & -0.68 & -0.96 & -0.40 & 0.000 \\
\hline Living with patients with chronic diseases & 0.02 & 0.00 & 0.04 & 0.014 \\
\hline \multicolumn{5}{|l|}{ Perceived self-efficacy } \\
\hline Female & 0.22 & 0.08 & 0.36 & 0.002 \\
\hline Age $30-39$ years old & 0.23 & 0.07 & 0.39 & 0.005 \\
\hline Age $40-49$ years old & 0.23 & 0.06 & 0.40 & 0.010 \\
\hline Age $50-59$ years old & 0.36 & 0.15 & 0.57 & 0.001 \\
\hline Age $60-69$ years old & 0.39 & 0.01 & 0.77 & 0.042 \\
\hline
\end{tabular}


individuals who had higher perceived barriers have worse COVID-19 self-protection behavior. They are likely to not behaving COVID-19 self-protection behavior because of some inconveniences.

Therefore, Thai government should have public policies to provide proper environment to promote COVID-19 self-protection behavior such as providing soap and alcohol gel, providing low-cost but effective masks, and providing effective physical distancing environment.

Even though, we totally believe that our findings are important for Thai public health policy makers for the improvement of COVID-19 self-protection behavior, some limitations should be discussed. This study distributed the survey online via social medias. Individuals who have limited access to internet or limited ability to response online questionnaires might not be able to participate. It is shown in the subjects' characteristics that the average age of subjects is 32.29 years old and the most age group is $20-29$ years old. The age group is likely to have higher internet access and higher ability to response online questionnaires than elderly. Generalizability of our findings should be limited to young Thai people. Second, this study was conducted in January 2021 which was the time of the second wave pandemic of COVID-19 in Thailand, we need to ask subjects to recall to the time of the first relaxed coronavirus lockdown which was from May to December 2020. Recall bias should be considered. However, we attempted to ensure that subjects have to recall to such time period by emphasizing the time period we asked in the subject information sheet which was the first page of our Google form ${ }^{\circledR}$ online questionnaire.

In conclusion, one-third of participants have proper COVID-19 self-protection behavior. Perceived self-efficacy is the strongest determinant of COVID-19 self-protection followed by perceived threat and perceived barriers. To improve COVID-19 self-protection behavior, perception of self-efficacy should be primarily encouraged among Thai people.

\section{ACKNOWLEDGEMENT}

The authors would like to acknowledge all participants of this study who are willing to help our communities by providing important information on self-protection behavior and its determinants. We also would like to thank all experts who participate in this research as external reviewers.

\section{Conflict of interest}

No authors declare any conflict of interest related to this study.

\section{Funding}

This study is supported by Faculty of Pharmaceutical
Sciences, Naresuan University.

\section{Ethics approval}

This study was approved by the research committee of Naresuan University Institutional Review Board (NUIRB) (No. P10167/63).

\section{Article info:}

Received August 23, 2021

Received in revised form October 6, 2021

Accepted October 18, 2021

\section{REFERENCES}

1. World Health Organization. Timeline: WHO's COVID-19 response [cited 2021 Mar 22]. Available from: https://www.who. int/emergencies/diseases/novel-coronavirus-2019/interactivetimeline\#!

2. World Health Organization. COVID-19 WHO Appeal Geneva, Switzerland [updated 2020 May 24; cited 2021 Mar 22]. Available from: https://www.who.int/publications/m/item/covid-19who-appeal.

3. Centers for Disease Control and Prevention. Interim Clinical Guidance for Management of Patients with Confirmed Coronavirus Disease (COVID-19) [updated 2021 February 16; cited 2021 Mar 22]. Available from: https://www.cdc.gov/coronavirus/ 2019-ncov/hcp/clinical-guidance-management-patients.html.

4. Department of Disease Control; Ministry of Public Health. Recommendations for Self-Protection. Nonthaburi, Thailand; 2020.

5. Centers for Disease Control and Prevention. People at increase risk and other people who need to take extra precautions [updated 2021 March 15; cited 2021 Mar 22]. Available from: https://www. cdc.gov/coronavirus/2019-ncov/need-extra-precautions/index. html\#print.

6. Centers for disease control and prevention. How COVID-19 spreads [updated 2021 July 14; cited 2021 Oct 22]. Available from: https://www.cdc.gov/coronavirus/2019-ncov/prevent-getting-sick/how-covid-spreads.html.

7. World Health Organization. COVID-19 strategy update. Geneva, Switzerland: World Health Organization; 2020 [updated 2020 April 14; cited 2021 Mar 23]. Available from: https://www.who. int/publications/m/item/covid-19-strategy-update.

8. Thai Health Promotion Foundation. Advice for people about covid-19; 2020.

9. Centers for Disease Control and Prevention. Things to Know about the COVID-19 Pandemic [updated 2021 August 13; cited 2021 Oct 7]. Available from: https://www.cdc.gov/coronavirus/ 2019-ncov/your-health/need-to-know.html.

10. Centers for Disease Control and Prevention. How to protect yourself and others 2021 [updated 2021 March 8; cited 2021 Mar 23]. Available from: https://www.cdc.gov/coronavirus/2019ncov/ prevent-getting-sick/prevention.html.

11. Glanz K, Rimer BK, Viswanath K. Health behavior and health education: Theory, research, and practice, $4^{\text {th }}$ ed. San Francisco, CA, US: Jossey-Bass; 2008.

12. Costa MF. Health belief model for coronavirus infection risk determinants. Rev Saude Publica. 2020;54:47.

13. Fathian-Dastgerdi Z, Khoshgoftar M, Tavakoli B, Jaleh M. Factors associated with preventive behaviors of COVID-19 among adolescents: Applying the health belief model. Res Soc Adm Pharm. 2021;17(10):1786-90.

14. Jose R, Narendran M, Bindu A, Beevi N, Manju L, Benny PV. Public perception and preparedness for the pandemic COVID 19: A Health Belief Model approach. Clinical Epidemiology and Global Health. 2021;9:41-6.

15. United Nations International Children's Emergency Fund. 
Everything you need to know about washing your hands to protect against coronavirus (COVID-19) [updated 2020 September 17; cited 2020 Mar 20]. Available from: https://www.unicef. org/coronavirus/everything-you-need-know-about-washing-yourhands-protect-against-coronavirus-covid- 19.

16. Shahnazi H, Ahmadi-Livani M, Pahlavanzadeh B, Rajabi A, Hamrah MS, Charkazi A. Assessing preventive health behaviors from COVID-19: a cross sectional study with health belief model in Golestan Province, Northern of Iran. Infect Dis Povert. 2020;
9(1):157

17. Yehualashet SS, Asefa KK, Mekonnen AG, Gemeda BN, Shiferaw WS, Aynalem YA, et al. Predictors of adherence to COVID-19 prevention measure among communities in North Shoa Zone, Etiopia based on health belief model: a crosssectional study. Plos One. 2021;16(1):e0246006.

18. Jadil Y, Ouzir M. Exploring the predictors of health-protective behavior during the COVID-19 pandemic: A multi-country comparison. Environ Res. 2021;199:111376. 


\section{Appendix}

Table A1. Responses on self-protection behavior.

\begin{tabular}{lrrrrr}
\hline Self-protection behavior & Never & Rarely & Sometime & Often & Always \\
\hline 1. Handwashing & & & & & \\
$\quad$ - before eating food & $7(1.72)$ & $24(5.90)$ & $64(15.72)$ & $141(34.64)$ & $171(42.26)$ \\
- after using toilet & $10(2.46)$ & $18(4.42)$ & $48(11.79)$ & $96(23.59)$ & $235(57.74)$ \\
- after coughing/sneezing & $28(6.88)$ & $40(9.83)$ & $89(21.87)$ & $135(33.17)$ & $115(28.26)$ \\
- after touching objects in public & $1(0.25)$ & $17(4.17)$ & $47(11.52)$ & $92(22.25)$ & $251(61.52)$ \\
\hline 2. Wearing mask in public & $0(0.00)$ & $1(0.25)$ & $7(1.72)$ & $33(8.09)$ & $367(89.95)$ \\
\hline 3. Physical distancing & $6(1.47)$ & $28(6.88)$ & $97(23.83)$ & $158(38.82)$ & $118(28.99)$ \\
\hline
\end{tabular}

Table A2. Responses on HBM framework.

\begin{tabular}{|c|c|c|c|c|c|}
\hline HBM framework & $\begin{array}{l}\text { Strongly } \\
\text { disagree }\end{array}$ & Disagree & Undecided & Agree & $\begin{array}{l}\text { Strongly } \\
\text { agree }\end{array}$ \\
\hline \multicolumn{6}{|l|}{ Perceived susceptibility } \\
\hline $\begin{array}{l}\text { 1. I have a chance to be infected through secretion } \\
\text { or saliva from COVID-19 patients. }\end{array}$ & $66(16.18)$ & $42(10.29)$ & $56(13.73)$ & $52(12.75)$ & $192(47.06)$ \\
\hline 2. I do not have a risk for COVID-19 diseases. & $125(30.64)$ & $66(16.18)$ & $76(18.63)$ & $77(18.87)$ & $64(15.69)$ \\
\hline \multicolumn{6}{|l|}{ Perceived severity } \\
\hline $\begin{array}{l}\text { 1. I will have a chance to be pneumonia if I get } \\
\text { infected by COVID-19 virus. }\end{array}$ & $12(2.95)$ & $17(4.18)$ & $73(17.94)$ & $115(28.26)$ & $190(46.68)$ \\
\hline $\begin{array}{l}\text { 2. I will have a chance to death if I get infected by } \\
\text { COVID-19 virus. }\end{array}$ & $29(7.13)$ & $30(7.37)$ & $105(25.80)$ & $91(22.36)$ & $152(35.35)$ \\
\hline $\begin{array}{l}\text { 3. I will be unable to stay in public if I get infected } \\
\text { by COVID-19 virus. }\end{array}$ & $92(22.55)$ & $69(16.91)$ & $98(24.02)$ & $58(14.22)$ & $91(22.30)$ \\
\hline 4. COVID-19 could be treated by drug(s). & $17(4.17)$ & $29(7.11)$ & $86(21.08)$ & $137(33.58)$ & $139(34.07)$ \\
\hline $\begin{array}{l}\text { 5. I will have a chance to be severely infected or death } \\
\text { if get infected by COVID-19 virus and have a } \\
\text { chronic disease(s). }\end{array}$ & $9 \quad(2.21)$ & $5(1.23)$ & $29(7.13)$ & $59(14.50)$ & $305(74.94)$ \\
\hline \multicolumn{6}{|l|}{ Perceived benefits } \\
\hline $\begin{array}{l}\text { 1. Handwashing with soap or alcohol gel helps me } \\
\text { to prevent COVID-19 spread and infection. }\end{array}$ & $2(0.49)$ & $2(0.49)$ & $20 \quad(4.91)$ & $96(23.59)$ & $287(70.52)$ \\
\hline $\begin{array}{l}\text { 2. Waring mask in public helps me to prevent } \\
\text { COVID-19 spread and infection. }\end{array}$ & $0 \quad(0.00)$ & $5(1.21)$ & $9 \quad(2.21)$ & $85(20.83)$ & $309(75.74)$ \\
\hline $\begin{array}{l}\text { 3. Physical distancing for at least } 1-2 \text { meters helps } \\
\text { me to prevent COVID-19 spread and infection. }\end{array}$ & $3 \quad(0.74)$ & $3(0.74)$ & $35(8.58)$ & $105(25.74)$ & $262(64.22)$ \\
\hline $\begin{array}{l}\text { 4. Self-protection as recommended by Thai govern- } \\
\text { ment helps us to reduce the number of infected } \\
\text { individuals or death. }\end{array}$ & $5(1.23)$ & $14(3.44)$ & $50(12.29)$ & $103(25.31)$ & $235(57.74)$ \\
\hline \multicolumn{6}{|l|}{ Perceived barriers } \\
\hline 1. Handwashing regularly is difficult to do. & $178(43.63)$ & $119(29.17)$ & $48(11.76)$ & $40 \quad(9.80)$ & $23 \quad(5.64)$ \\
\hline 2. At current, alcohol gel is difficult to find. & $200(49.14)$ & $122(29.98)$ & $56(13.76)$ & $21(5.16)$ & $8 \quad(1.97)$ \\
\hline 3. Alcohol gel is too expensive over its benefits. & $118(28.99)$ & $111(27.27)$ & $107(26.29)$ & $47(11.55)$ & $24 \quad(5.90)$ \\
\hline $\begin{array}{l}\text { 4. Wearing mask causes breathing difficulty and } \\
\text { disturbs daily of living. }\end{array}$ & $74(18.23)$ & $81(19.95)$ & $68(16.75)$ & $109(26.85)$ & $74(18.23)$ \\
\hline 5. At current, mask is difficult to find. & $164(40.20)$ & $116(28.43)$ & $29(16.91)$ & $36 \quad(8.82)$ & $23 \quad(5.64)$ \\
\hline 6. Mask is too expensive over its benefits. & $115(28.19)$ & $104(25.49)$ & $75(18.38)$ & $59(14.46)$ & $55(13.48)$ \\
\hline 7. Physical distancing in public is difficult to do. & $58(14.22)$ & $76(18.63)$ & $77(18.87)$ & $104(25.49)$ & $93(22.79)$ \\
\hline \multicolumn{6}{|l|}{ Perceived self-efficacy } \\
\hline 1. I am able to wear a mask in public. & $1 \quad(0.25)$ & $6(1.41)$ & $16 \quad(3.92)$ & $75(18.38)$ & $310(75.98)$ \\
\hline $\begin{array}{l}\text { 2. I confidently perform physical distancing for at } \\
\text { least 1-2 meters when staying with others. }\end{array}$ & $20 \quad(4.90)$ & $45(11.03)$ & $132(32.35)$ & $111(2721)$ & $100(24.51)$ \\
\hline 3. I wash my hands with no remind from others. & $2(0.49)$ & $7 \quad(1.72)$ & $19 \quad(4.66)$ & $73(17.89)$ & $307(75.25)$ \\
\hline \multicolumn{6}{|l|}{ Cues to action } \\
\hline $\begin{array}{l}\text { 1. I perform self-protection behavior because of the } \\
\text { advertisement. }\end{array}$ & $2(0.49)$ & $8 \quad(1.96)$ & $29(7.11)$ & $128(31.37)$ & $241(59.07)$ \\
\hline $\begin{array}{l}\text { 2. My family and friends suggest me to perform } \\
\text { self-protection behavior. }\end{array}$ & $19(4.66)$ & $86 \quad(6.13)$ & $52(12.75)$ & $106(25.98)$ & $206(50.49)$ \\
\hline $\begin{array}{l}\text { 3. I perform self-protection behavior because of } \\
\text { Thai national policy. }\end{array}$ & $31(7.60)$ & $48(11.76)$ & $62(15.20)$ & $105(25.74)$ & $162(39.71)$ \\
\hline $\begin{array}{l}\text { 4. Places such as department stores or communities } \\
\text { provide sufficient environment for handwashing } \\
\text { or physical distancing. }\end{array}$ & $6 \quad(1.47)$ & $18(4.41)$ & $44(10.78)$ & $114(27.94)$ & $226(55.39)$ \\
\hline
\end{tabular}


Table A3. Association between modifying factors and individual perceptions.

\begin{tabular}{|c|c|c|c|c|}
\hline & \multirow[t]{2}{*}{ Beta coefficient } & \multicolumn{2}{|c|}{$95 \% \mathrm{CI}$} & \multirow[t]{2}{*}{$P$-value } \\
\hline & & Min & Max & \\
\hline \multicolumn{5}{|l|}{ Perceived susceptibility } \\
\hline No modifying factors & - & - & - & - \\
\hline \multicolumn{5}{|l|}{ Perceived severity } \\
\hline Age $40-49$ years old & 0.22 & 0.03 & 0.41 & 0.025 \\
\hline Age $50-59$ years old & 0.32 & 0.09 & 0.55 & 0.007 \\
\hline \multicolumn{5}{|l|}{ Perceived benefits } \\
\hline Female & 0.20 & 0.07 & 0.33 & 0.002 \\
\hline Income $15,001-50,000$ bath/month & 0.15 & 0.04 & 0.26 & 0.007 \\
\hline \multicolumn{5}{|l|}{ Perceived barriers } \\
\hline Age $30-39$ years old & -0.45 & -0.66 & -0.24 & 0.000 \\
\hline Age $40-49$ years old & -0.53 & -0.76 & -0.30 & 0.000 \\
\hline Age $50-59$ years old & -0.68 & -0.96 & -0.40 & 0.000 \\
\hline Living with patients with chronic diseases & 0.02 & 0.00 & 0.04 & 0.014 \\
\hline \multicolumn{5}{|l|}{ Perceived self-efficacy } \\
\hline Female & 0.22 & 0.08 & 0.36 & 0.002 \\
\hline Age $30-39$ years old & 0.23 & 0.07 & 0.39 & 0.005 \\
\hline Age $40-49$ years old & 0.23 & 0.06 & 0.40 & 0.010 \\
\hline Age 50-59 years old & 0.36 & 0.15 & 0.57 & 0.001 \\
\hline Age 60-69 years old & 0.39 & 0.01 & 0.77 & 0.042 \\
\hline
\end{tabular}

